\title{
Remix, cover, mash : remediating phonographic-oral practice online
}

Citation for published version (APA):

Michielse, M. (2015). Remix, cover, mash : remediating phonographic-oral practice online. [Doctoral Thesis, Maastricht University]. Maastricht University. https://doi.org/10.26481/dis.20150622mm

Document status and date:

Published: 01/01/2015

DOI:

10.26481/dis.20150622mm

Document Version:

Publisher's PDF, also known as Version of record

\section{Please check the document version of this publication:}

- A submitted manuscript is the version of the article upon submission and before peer-review. There can be important differences between the submitted version and the official published version of record.

People interested in the research are advised to contact the author for the final version of the publication, or visit the DOI to the publisher's website.

- The final author version and the galley proof are versions of the publication after peer review.

- The final published version features the final layout of the paper including the volume, issue and page numbers.

Link to publication

\footnotetext{
General rights rights.

- You may freely distribute the URL identifying the publication in the public portal. please follow below link for the End User Agreement:

www.umlib.nl/taverne-license

Take down policy

If you believe that this document breaches copyright please contact us at:

repository@maastrichtuniversity.nl

providing details and we will investigate your claim.
}

Copyright and moral rights for the publications made accessible in the public portal are retained by the authors and/or other copyright owners and it is a condition of accessing publications that users recognise and abide by the legal requirements associated with these

- Users may download and print one copy of any publication from the public portal for the purpose of private study or research.

- You may not further distribute the material or use it for any profit-making activity or commercial gain

If the publication is distributed under the terms of Article $25 \mathrm{fa}$ of the Dutch Copyright Act, indicated by the "Taverne" license above, 


\section{Nederlandse Samenvatting}

Remix, Cover, Mash onderzoekt de manier waarop grote groepen online participanten zich muziek eigen maken door actief mee te spelen met, en variaties te maken op, populaire muziek op verschillende online platforms. Bij veel hits die vandaag de dag in de Top 40 belanden zien we tientallen, soms honderden, muzikale variaties verschijnen op websites zoals YouTube. Deze variaties worden doorgaans niet gemaakt door bekende, gevestigde artiesten, maar door hobbyisten of, zoals ik hen in dit proefschrift noem, 'enthousiastelingen' (enthusiasts). Hoewel de praktijken van deze enthousiastelingen vaak gezien worden als eenvoudige vormen van kopieergedrag of makkelijke manieren om mee te liften met het succes van bekende artiesten, laat dit proefschrift zien hoe deze activiteiten als belangrijke vormen van leren en experimenteren beschouwd kunnen worden.

Het proefschrift doet dit door deze praktijken binnen de context van 'fonografische oraliteit' te plaatsen. Fonografische oraliteit beschrijft een vorm van muzikale interactie die sterk samenhangt met de opkomst van opnametechnologieën en fysieke geluidsdragers (zoals fonograafcilinders, grammofoonplaten, cassettes en CD's). Met de komst van geluidsdragers werd het voor muzikanten voor het eerst mogelijk om thuis mee te spelen met, en te improviseren op, de muziek van een breed scala aan artiesten en bands. Dit bleek een effectieve manier om kennis en vaardigheden op te doen. Zo hebben sinds het begin van de twintigste eeuw hele generaties muzikanten zich allerlei technieken en muzikale formules aangeleerd door thuis te experimenteren met bestaande opgenomen muziek. Sinds de opkomst van de personal computer en het internet zien we echter dat dergelijke fonografisch-orale vormen van leren aan het veranderen zijn en steeds meer verschuiven naar een online context waarbij een grote verscheidenheid aan digitale technologieën, online communities en commerciële platformen een rol spelen. Dit brengt nieuwe mogelijkheden met zich mee, maar, zoals ik in dit proefschrift laat zien, ook nieuwe problemen en uitdagingen.

De vraag die centraal staat in dit proefschrift is dan ook hoe een dergelijke fonografisch-orale praktijk precies vorm krijgt binnen een online context. Hoe leren online participanten van elkaar door gezamenlijk bewerkingen te maken 
op bestaande opgenomen muziek? Wat voor kennis en vaardigheden doen zij op? En wat voor nieuwe mogelijkheden en problemen komen zij tegen? In dit proefschrift onderzoek ik deze vragen door in te zoomen op drie online communities waarin participanten variaties maken op bestaande muziek: een covercommunity op YouTube, een remix-community op IndabaMusic en een mashup-community op Mashstix. Ik maak hierbij gebruik van een virtueeletnografische onderzoeksmethode waarin elementen zoals online observatie, participatie en interviews een centrale rol spelen. Door tijd door te brengen met de participanten zelf en door hun alledaagse praktijken online te bestuderen, tracht ik een gedetailleerd beeld te schetsen van de manier waarop fonografisch-orale vormen van participeren en leren zich online manifesteren.

Een belangrijk concept hierbij is 'remediatie': het idee dat er, wanneer zich nieuwe media aandienen, een herschikking plaatsvindt in het medialandschap waarbij verschillende media zich opnieuw tot elkaar moeten verhouden. Nieuwe media adopteren elementen uit oude media, terwijl oude media hun rol ten opzichte van nieuwe media opnieuw definiëren. Hoewel remediatietheorie meestal gebruikt wordt om naar media zelf te kijken (of anders naar de content van die media), laat ik in dit proefschrift zien hoe dit concept ook gebruikt kan worden om mediapraktijken te bestuderen. Met de opkomst van nieuwe media, zullen ook bestaande praktijken zich een nieuwe rol moeten aanmeten in het medialandschap. Dit is niet alleen een kwestie van zich aanpassen aan veranderende technologische mogelijkheden, maar ook van het aftasten van nieuwe sociale (en vaak ook commerciële) omstandigheden. In het geval van fonografische oraliteit zien we bijvoorbeeld hoe niet alleen digitale technologieën een rol spelen in dit proces van remediatie, maar ook de opkomst van een bredere participatiecultuur waarin commerciële bedrijven en online participanten in toenemende mate met elkaar verbonden, en van elkaar afhankelijk, zijn. Ook de opkomst van zogenaamde online praktijkgemeenschappen (communities of practice) is hierbij van belang, aangezien deze het mogelijk maken om muzikale vaardigheden en kennis op nieuwe collectieve manieren te trainen en uit te wisselen.

Dit wordt duidelijk zichtbaar in het eerste empirische hoofdstuk waarin coverpraktijken op YouTube centraal staan. In dit hoofdstuk laat ik zien hoe het uploaden en delen van cover-video's voor veel participanten niet zozeer een manier is om bij een groot publiek bekendheid te verwerven of om gemakkelijk views te genereren (iets dat in de literatuur vaak 'viraling' of 'meming' genoemd wordt), maar vooral een strategie is om deel uit te kunnen maken van 
een grotere groep van mede-participanten en zo van anderen te kunnen leren. Via de 'related video'-optie is het op YouTube bijvoorbeeld mogelijk om precieze vergelijkingen te maken tussen verschillende manieren waarop een nummer muzikaal geïnterpreteerd kan worden (iets dat ik in dit proefschrift 'translatie' noem). Daarnaast is het mogelijk om cover-video's expliciet te linken aan zogenaamde 'tutorial-video's' waarin participanten elkaar (in woord, beeld en geluid) uit kunnen leggen hoe een bepaald lied muzikaal is opgebouwd. Op die manier kunnen op YouTube nieuwe, collectieve vormen van fonografischorale interactie plaatsvinden, waarbij participanten niet alleen van gevestigde artiesten leren, maar ook van elkaar. Dat deze nieuwe mogelijkheden niet alleen maar voordelen met zich meebrengen, maar soms ook twijfels en problemen, wordt duidelijk aan het eind van het hoofdstuk. Hier laat ik zien dat participanten op YouTube soms moeite hebben een goede balans te vinden tussen de relatief private sfeer van de woon- of slaapkamer van waaruit deze video's vaak worden opgenomen (de zogenaamde 'bedroom performance') en de meer publieke sfeer van het internet waarin elke video in potentie bekeken, beoordeeld en becommentarieerd kan worden door honderden, en soms duizenden, mede-YouTube gebruikers, overal ter wereld.

Het tweede empirische hoofdstuk zoomt in op remixcompetities op IndabaMusic.com. Voor deze competities stellen bekende artiesten zogeheten 'multitrack' bestanden beschikbaar van één of meerdere nummers uit hun repertoire. Participanten die zich inschrijven voor de competities mogen deze audiobestanden dan, onder strikt toezicht van de artiest, hergebruiken en bewerken in hun eigen mix. In het hoofdstuk stel ik dat de opkomst van deze remixcompetities niet alleen vragen oproept over mogelijke uitbuiting van participanten (free labour), maar ook belangrijke nieuwe mogelijkheden biedt als het gaat om fonografisch-orale participatie. Door mee te doen aan online competities leren participanten bijvoorbeeld snel ideeën te produceren voor, en bewerkingen te maken van, een breed scala aan (vaak onbekende) audiotracks. Dit is een vaardigheid die ik in het hoofdstuk muzikale 'vloeiendheid' (fluency) noem. Daarnaast leren participanten gevoel te ontwikkelen voor de creatieve mogelijkheden (affordances) van verschillende genres en stijlen en zich snel aan te passen aan de steeds veranderende omstandigheden en richtlijnen die de remixcompetities met zich meebrengen. Dit is iets wat ik muzikale 'flexibiliteit' (flexibility) noem. Digitale audiosoftware, zoals Cubase en Pro Tools, spelen hierbij een belangrijke rol, omdat deze programma's het 
mogelijk maken de bovengenoemde vaardigheden op zeer verscheidene manieren te testen en ontwikkelen.

In het derde empirische hoofdstuk bestudeer ik de mashup community Mashstix.com. In deze community experimenteren participanten met het recombineren van verschillende muzikale tracks. Zij doen dit door de vocalen van een bestaand nummer digitaal te mixen met de instrumentale track van een ander nummer. Op deze manier ontstaat een mengvorm (een mashup) waarin twee verschillende audiotracks samensmelten tot één. Hoewel mashuppraktijken vaak gezien worden als vormen van muzikale piraterij of subversiviteit, laat ik in dit hoofdstuk zien hoe mashup communities in werkelijkheid vooral gericht zijn op het opdoen van zeer specifieke muzikale kennis en vaardigheden. Zo spenderen participanten op Mashstix relatief veel tijd aan het systematisch archiveren, analyseren en annoteren van grote hoeveelheden audiobestanden. Dit gebeurt veelal met behulp van digitale software programma's en online databases waarmee de metadata van bestaande audiotracks (zoals toonsoort, tempo, geluidskwaliteit, en 'mixing key') in detail kunnen worden bestudeerd. Op deze manier leren participanten niet alleen technische en muzikale verbanden te leggen tussen specifieke audiotracks, maar leren zij ook meer over de eigenschappen en mogelijkheden van digitale opnametechnologieën en audioformats in het algemeen. Dit noem ik in het hoofdstuk een 'digitaal opnamebewustzijn' (digital recording consciousness). Dat hierbij ook bredere sociale en media-gerelateerde vaardigheden een rol spelen, wordt duidelijk aan het eind van het hoofdstuk waarin ik dieper inga op de verschillende manieren waarop makers van mashups hun (vaak illegale) bronmaterialen lokaliseren, bewerken en delen.

In het laatste hoofdstuk breng ik de bevindingen uit de verschillende empirische hoofdstukken weer terug naar het oorspronkelijke concept van fonografische oraliteit. Ik stel hierbij dat, hoewel sommige aspecten van fonografisch-orale participatie nog steeds duidelijk zichtbaar zijn in een online context, deze praktijk zich tegenwoordig toch op een beduidend andere manier manifesteert dan voorheen. Zo zorgt de opkomst van online praktijkgemeenschappen er voor dat fonografisch-orale participatie meer en meer een collectief en gedeeld proces wordt, waarbij private en publieke activiteiten (en vormen van oefenen en optreden) in toenemende mate door elkaar beginnen te lopen. Ook stel ik dat analoge en digitale technologieën in een online context vaak hand in hand gaan en dat 'allosonische' vormen van toe-eigening (nazingen en na-spelen) en 'autosonische' vormen van toe-eigening (sampling) 
vaak naadloos in elkaar overgaan. Aan de ene kant zorgt dit er voor dat muzikale participatie toegankelijk wordt voor een relatief brede groep van participanten. Aan de andere kant brengt dit ook nieuwe uitdagingen met zich mee, bijvoorbeeld doordat niet alleen muzikale, maar ook allerlei technische, sociale en media-gerelateerde vaardigheden een rol beginnen te spelen. Tot slot stel ik dat de opkomst van een participatiecultuur soms tegenstrijdigheden met zich meebrengt. Hierdoor weten participanten niet altijd waar zij staan of hoe zij zich dienen te verhouden ten opzichte van gevestigde artiesten en de culturele industrie. Zo worden sommige vormen van online fonografische-orale participatie openlijk gedoogd en zelfs expliciet aangemoedigd door de muziekindustrie, terwijl andere activiteiten nog altijd argwanend (of zelfs afkeurend) worden benaderd. Een terugkerend probleem hierbij is dat fonografisch-orale participatie vaak niet als zodanig herkend wordt en nog altijd wordt verward met vormen van muzikale diefstal of piraterij. Dit levert helaas nog regelmatig misverstanden op tussen participanten en de culturele industrie.

Het is om deze reden dan ook dat ik claim dat het idee van remediatie hier verhelderend kan werken, aangezien het een belangrijk theoretisch inzicht geeft in de huidige processen en onderhandelingen die zich afspelen rond deze muzikale activiteiten. Hiervoor dienen we de koppeling tussen remediatie en culturele praktijken echter wel als complexer te beschouwen dan dat het in de huidige academische literatuur wordt voorgesteld. Zo is de remediatie van een praktijk niet een kortstondig en lineair proces, maar een langdurig traject, waarbij verschillende technologische, sociale en commerciële aspecten een rol spelen die elkaar over en weer beïnvloeden. Ook is een proces van remediatie niet iets dat enkel en alleen de praktisanten zelf betreft, maar ook andere partijen: of het nu gaat om de muziekindustrie, bredere groepen van online gebruikers, mediabedrijven of de academische wereld. Het is mede door de complexiteit van dit proces dat de onderliggende praktijk soms vergeten wordt. Aan het eind van het proefschrift stel ik dan ook dat we de vaardigheden en technieken van online remixes, covers en mashups niet uit het oog moeten verliezen, omdat die de basis vormen van deze praktijken. Alleen door processen van leren en experimenteren serieus te nemen en deze in detail te blijven bestuderen, wordt het mogelijk om verder inzicht te krijgen in deze veranderende muzikale praktijken. 